\title{
The effect of endurance training on the neovascularization of skeletal musculature ${ }^{1}$
}

\author{
Efeito do treinamento de endurance sobre a neovascularização \\ da musculatura esquelética
}

\author{
1. Research performed at Department of Anatomy, Federal University of Pernambuco (UFPE), Brazil. \\ 2. Master in Biophysic, Fellow PhD degree in Neuroscience, UFPE, Brazil. \\ 3. Fellow Master degree in Pathology, UFPE, Brazil. \\ 4. Assistant Professor, Department of Physical Education, UFPE, Brazil. \\ 5. Associate Professor, Department of Anatomy, UFPE, Brazil.
}

Celina Cordeiro de Carvalho ${ }^{2}$, Danielle Augusta de Sá Xerita Maux ${ }^{3}$, Tetsuo Tashiro ${ }^{4}$, Sílvia Regina Arruda de Moraes ${ }^{5}$

\begin{abstract}
Purpose: To quantify the capillaries in the skeletal muscular tissue of mice with induced peripheral arterial insufficiency, after endurance training. Methods: It was used Wistar mice in 70 days age range, subjected to the total occlusion of right femoral artery. The animals were divided into two groups: sedentary group (SG; $n=05)$, subjected to activities in the cage; and trained group (TG; $\mathrm{n}=05$ ), subjected to an endurance training in cycle ergometer twice a day $17 \mathrm{~m} / \mathrm{min}$, by $5 \mathrm{minutes}$, 5 days per week during 10 weeks. The analysis was realized by the histologic observation of the vastus medialis muscle of injured member. Results: The average number of capillaries in the muscular tissue was greater in TG $(5,2 \pm 0,83)$ than in SG $(1,6 \pm 1,14)(p<0,05)$. Conclusion: In animals with induction of peripheral arterial insufficiency, the endurance training provides a process of muscular adaptation which is observed by the increase in the number of capillaries of animals subjected to this kind of training.
\end{abstract}

Key words: Femoral Artery. Physical Endurance.

\section{RESUMO}

Objetivo: Quantificar os capilares no tecido muscular esquelético em ratos com insuficiência arterial periférica induzida, após treinamento de endurance. Métodos: Foram utilizados ratos Wistar, idade de 70 dias, submetidos à oclusão total da artéria femoral direita. Os animais foram divididos em grupo sedentário (GS; $\mathrm{n}=05)$, submetidos a atividades na própria gaiola; e grupo treinado (GT; $\mathrm{n}=05)$, submetidos ao treinamento de endurance em ciclo ergômetro, duas vezes ao dia, 17 $\mathrm{m} / \mathrm{min}$, por 5 minutos, 5 dias por semana, durante 10 semanas. A análise foi realizada pela observação histológica do músculo vasto medial do membro afetado. Resultados: O número médio de capilares no tecido muscular foi de 5,2 $\pm 0,837$ $(\mathrm{p}<0,05)$ no GT e de 1,6 \pm 1,140 no GS. Conclusão: Em animais com indução da insuficiência arterial periférica, submetidos ao treinamento de endurance, há um processo de adaptação muscular, observado pelo aumento do número de capilares nos animais submetidos a esse tipo de treinamento.

Descritores: Artéria Femoral. Resistência Física.

\section{Introduction}

Studies have demonstrated that the exercise can be effective in the prevention and/or treatment of some of the more common chronic diseases of the last century, such as coronary heart diseases, diabetes Type 2 and obesity ${ }^{1,2}$. However, up to now, many of the basic mechanisms of adaptation of skeletal muscles to physical exercises must be clarified ${ }^{1}$. From the observation that there is an increase of collateral-dependent circulation and capillarity of muscle after the training, was concluded that physical exercises can stimulate the vascularization by the processes of angiogenesis and arteriogenesis ${ }^{3}$. The angiogenesis is a process that involve arise of capillaries trough a pre-existing capillary bed, resulting in an increase of capillary density ${ }^{4}$. The process occurs in skeletal muscles in response to physical exercise and can be histologically evident from the $12^{\text {th }}$ day of training ${ }^{3}$. The arteriogenesis is characterized by a rapid proliferation of preexisting collateral arteries in response to an inflammatory reaction ${ }^{5,6}$. Injured tissues appear as a strong stimulus for the angiogenesis. It has been demonstrated that injured skeletal muscle can induce these process, as well as hypoxia; although this one does not appear as a demand to angiogenesis occur ${ }^{7}$. The hypothesis that physical exercise causes increase of capillarization in muscular tissue has been demonstrated in various experimental studies ${ }^{8,9,10,11}$ and in human beings ${ }^{12}$. A previous study in rats subjected to bilateral femoral artery ligation ${ }^{13}$, causing peripheral arterial insufficiency, showed that blood circulation of all calf, so the proximal component as the distal segment, was significant higher 
in the group of trained animals. This includes the collateral-dependent circulation for the tissues of trained animals, which was approximately $70 \%$ higher than the ones of sedentary group. Besides that, the experimental study in rats with endurance training during eight weeks was effective to cause an increase of average number of capillaries in skeletal muscular tissue, although this effect was more evident after twelve weeks of training ${ }^{11}$. However, it was not determined if this effect was progressive in the increase of number of capillaries in an intermediate phase between the two analyzed periods of training. Thus, the aim of this study was to verify the effects of endurance training in a period of ten weeks on the neovascularization of skeletal muscular tissue in animals subjected to induction of peripheral arterial insufficiency.

\section{Methods}

\section{Animals}

10 albino male Wistar rats, young adults were used, in 70 days age range, weighing, initially, about $250 \mathrm{~g}$. The animals came from the vivarium of Federal Rural University of Pernambuco and Center of Research Aggeu Magalhães (CpqAM) - Fiocruz. The animals were kept under standard vivarium conditions.

\section{Experimental procedures}

The animals were divided aleatory into two groups: group of sedentary animals $(n=05)$ and group of trained animals $(n=05)$. The group trained was subjected to a walk in cycle ergometer (developed by the Department of Mechanics of Center of Technologic Formation CEFET - PE) with a speed of $17 \mathrm{~m} / \mathrm{min}$, by 5 minutes, twice a day, during 10 days, to familiarize with the protocol according to Yang ${ }^{14}$. The other animals were subjected to activities only in the cage. At eleventh day, the two groups of animals were anesthetized with a solution of xilazine hydrochloride (Rompum ${ }^{\circledR}-$ Bayer) and ketamine $\left(\operatorname{Ketalar}^{\circledR}\right)(0,2 \mathrm{ml} / 100 \mathrm{~g}$ of weight), intramuscular and was realized an incision of approximately $3 \mathrm{~cm}$ from the inguinal ligament in the intern region of right hind leg of animal allowing the emphasizing of right femoral artery that was dissected in its more proximal region and realized the ligature with cotton thread $n^{\circ} 50$ (Corrente ${ }^{\circledR}$ ) up to its total occlusion. The external suture was made by three double points with suture thread Catigut simple 4-0. At the end of the procedure, the topic antibiotic of rovamycine (Rifocina ${ }^{\circledR}$ - Hoechst) was administered in the surgical wound daily during 3 days. Three days after the surgery, the animals of group trained were subjected to continuous endurance training in cycle ergometer, during 10 weeks, twice a day (morning and afternoon), five days per week, walking at a speed of $17 \mathrm{~m} / \mathrm{min}$, during five minutes according to the protocol of Yang ${ }^{14}$ modified. The endurance training was not realized progressively but continuously, thus, the speed $(17 \mathrm{~m} / \mathrm{min})$ and the time of training (5minutes) were kept. The animals of group trained were sacrificed at the day immediately after the end of training, together with the animals of group sedentary. The sacrifice was made after anesthetize the animals with a solution of xilazine hydrochloride (Rompum ${ }^{\circledR}$ - Bayer) and ketamine $\left(\right.$ Ketalar $\left.^{\circledR}\right)$ intramuscular. The right vastus medialis muscle of all animals was dissected and afterwards a piece of $5 \mathrm{~mm}$ was collected. The samples were fixed in solution of Bouin $(75 \mathrm{ml}$ of aqueous solution of picric acid, $20 \mathrm{ml}$ of formaldehyde at $40 \%$ and $5 \mathrm{ml}$ of glacial acetic acid) and after 24 hours, changed by a solution of alcohol at $70 \%$ staying in this solution up to histological process of material. The samples of right vastus medialis muscle were included in paraffin and were realized transversal cuts of $6 \mu \mathrm{m}$ of thickness, stained with Hematoxylin-Eosin (HE) and mounted between glass and coverglass with synthetic resin (Entellan ${ }^{\circledR}-$ Merck).

\section{Histomorphometric analysis}

The average number of capillaries was estimated by the count, in each animal, of 20 microscopic fields obtained by chance among images analyzed with the software ATI TV player 6.3 coupled with an optical microscope Leica (zoom lens of 40X) and a video camera Samsung (Model SHC-410NAD). The reading was realized from the right inferior angle, moving the lamina in a zigzag way up to the portion more superior. The data were statistically analyzed using the test of MannWhitney with the level of significance of $5 \%$ in all cases.

\section{Results}

After 10 weeks of endurance training it was observed an increase of the number of capillaries in muscular tissue in the animals of group trained $(5,2 \pm 0,83, p<0,05)$ when compared with the animals of group sedentary $(1,6 \pm 1,14)$ (Figures 1 and 2).

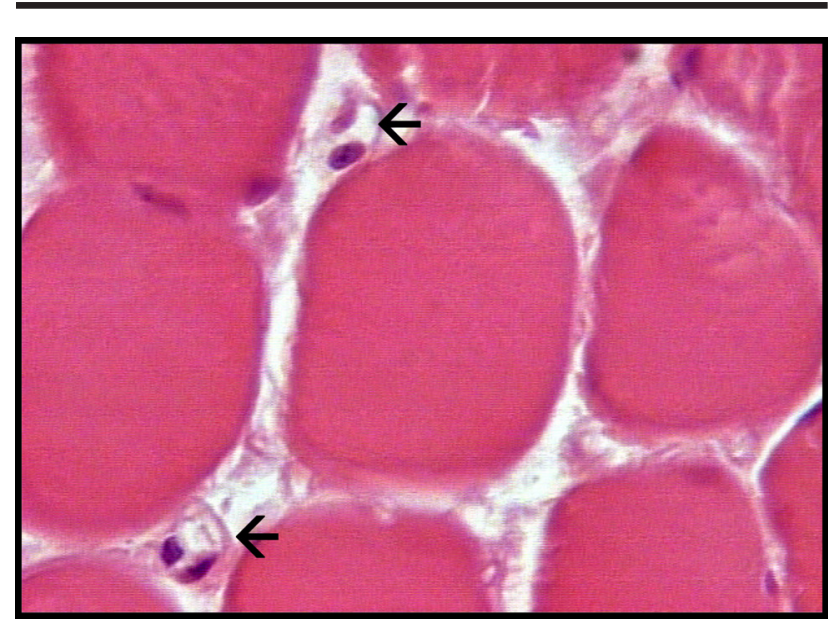

FIGURE 1 - Photomicrography of right vastus medialis muscle. Transversal cut of the portion more proximal to the occlusion of right femoral artery showing the endothelial cells of capillaries (arrow) between the muscular bundles. Hematoxylin-Eosin-400x. 


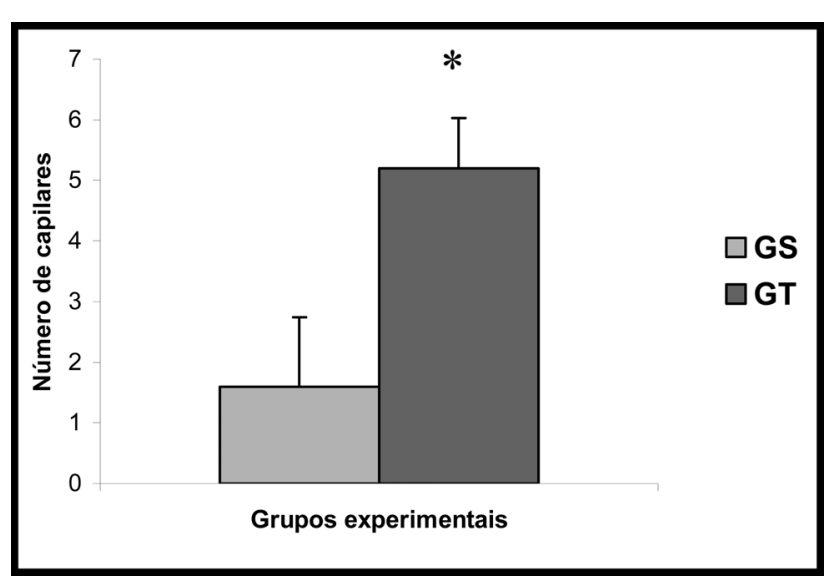

FIGURE 2 - Effect of endurance training during 10 weeks on the number of capillaries of right vastus medialis muscle. The data are represented as average \pm SD of number of capillaries; Group sedentary $(\mathrm{GS})=05$; Group trained $(\mathrm{GT})=05$. ${ }^{*} p<0,05$ (test of Mann-Whitney).

\section{Discussion}

The present study, obtained from the experimental model used to analyze the number of capillaries in the skeletal muscular tissue of animals with induction of peripheral arterial insufficiency, shows results consistent with the literature, using animals of laboratory subjected to endurance training ${ }^{3,11,13,15,16,17}$. With the occlusion of the femoral artery, were created acute signals of peripheral arterial insufficiency, characterized by the unsuitable blood flow for the involved musculature. Thus, the flow reserve for the right inferior member was decreased, however, the ability of collateral distal flow for this member remains sufficient to supply the basic tissue needs of muscular groups, and does not produce signals of ischemia at rest and/or tissue necrosis. It has been experimentally demonstrated that physical exercise increases the circulation, the capillarity and the functional ability of analyzed animals $3,11,13,15,16,17$. Physical exercise in humans also induces the vascular adaptations that improve the blood flow of skeletal musculature ${ }^{18,19,20}$. However, other studies are necessary to define the quantity, the frequency, the kind of physical exercise and also the kind of caloric restraint needed to increase the beneficial effects of the influence of these important factors on the energetic balance in humans ${ }^{21}$. Our results suggest that endurance training during 10 weeks in animals with occlusion of femoral artery induces adaptable changes in muscular tissue of areas close to the occlusion. These adaptations were observed histomorphometrically by the increase of the number of capillaries, improving the blood flow of the musculature during the physical exercise. Possibly, this capillarity induced by the physical exercise in ischemic muscles is a result of the process of angiogenesis. At the beginning phase of angiogenesis it is observed the proliferation of endothelial cells, which is crucial to form new capillaries ${ }^{17}$. This proliferation is stimulated when the flow becomes fast or turbulent, above or under the arterial stenosis ${ }^{22}$. Thus, the angiogenesis would act as a component of multifactor adaptation to physical exercise ${ }^{3,18}$. The physical exercise also induces peripheral adaptations that increase the aerobic ability of muscle by the increase of number and volume of mitochondria, improving the capillary density of muscle in use. This physiologic adaptation must decrease the distance of diffusion between the capillaries and mitochondria, prolonging the time of transit of erythrocytes and increasing the area of surface for the change of nutrients between the microcirculation and the myocytes ${ }^{13,19}$. Carvalho e col. ${ }^{11}$ also subjected rats to endurance training during 8 and 12 weeks after the occlusion of femoral artery. They observed that from the eighth week of training, occurred an increase of number of capillaries that got on up to 12 weeks, although there was not difference when the two trained groups were compared. However, the quantity of capillaries found in the group of trained animals (during 8 to 12 weeks) was higher in relation to its respective group control. Comparing our results with this study, we can conclude that in the period between eight and ten weeks, the alteration found was little or even none in relation to the trained animals, probably due to the time of training that was not sufficient to cause any modification. In our study the group sedentary was observed during 10 weeks after the induction of peripheral arterial insufficiency and the average number of capillaries found was an intermediate value for the values described by Carvalho et al. ${ }^{11}$ in the period of 8 and 12 weeks after the occlusion. Since occurred an occlusive process, a tissue ischemia can has happened, what led to a release of vasodilator substances and factors of growth for the local of lesion ${ }^{1,13,23}$. Thus, we can conclude that, with the induction of a peripheral arterial insufficiency, vascular adaptations are created to compensate this loss of blood flow for the musculature and that these changes can be emphasized during the period of ten weeks of training.

\section{References}

1. Hamilton MT, Booth FW. Skeletal muscle adaptation to exercise: a century of progress. J Appl Physiol. 2000; 88: 327-31.

2. Schmieder FA, Camerota AJ. Intermitent claudication: magnitude of the problem, patient evaluation and therapeutic strategies. Am J Cardiol. 2001; 87(suppl): 3D-13D.

3. Lloyd PG, Prior BM, Yang HT, Terjung RL. Angiogenic growth factor expression in rat skeletal muscle in response to exercise training. J Physiol Heart Circ Physiol. 2003; 284: H1668-78.

4. Bombardini T. Therapeutic Angiogenesis: a new choice for ischemic patients. Laedership Med. 1997; 99(10): 8.

5. Buschmann I, Scharper W. Arteriogenesis versus angiogenesis: two mechanismis of vessel growth. News Physiol Sci. 1999; 14: 121-5.

6. Clauss M, Schaper W. Vascular endothelial growth factor: a jack-of-all-trades or a neonspecific stress gene? Circ Res. 2000; 86: 251-2.

7. Pevec WC, Ndoye A, Brinsky JL, Wiltse S, Cheung ATW. New blood vessels can be induced to invade ischemic skeletal muscle. J Vasc Surg. 1996; 24: 534-44. 
8. Lash JM, Bohmen HG. Functional adaptations of rats skeletal muscle arterioles to aerobic exercise training. J Appl Physiol. 1992; 6(72): 2052-62.

9. Soares JM. Effects of training on muscle capillary pattern: Intermittent vs continuos exercise. J Sport Med Phys Fitness. 1992; 32: 123-7.

10. Regensteiner JG, Meyer TJ, Krupski WC, Cranford LS, Hiatt WR. Hospital vs home-based exercise rehabilitation for patients with peripheral arterial occlusive disease. Angiology. 1997; 48(4): 291-300.

11. Carvalho CC, Chalegre ST, Tashiro T, Moraes SRA. Quantificação de capilares no tecido muscular esquelético em animais com insuficiência arterial periférica induzida submetidos a treinamento de endurance. Acta Cir Bras. 2004; 19(5): 487-94.

12. Hepple RT. Resistance and aerobic training in older man: effects on $\mathrm{VO}_{2}$ peak and the capillary supply to skeletal muscle. J Appl Physiol. 1997; 82(4): 1305-10.

13. Yang HT, Laughlin MH, Terjung RL. Prior exercise training increases collateral-dependent blood flow in rats after acute femoral artery occlusion. Am J Physiol Heart Circ Physiol. 2000; 279: H1890-7.

14. Yang H T. Training increases collateral-dependent muscle blood flow in aged rats. J Appl Physiol. 1995; 37(69): 1174-80.

15. Suzuki J, Gao M, Batra S, Koyama T. Effects of tradmill training on the arteriolar and venular portions of capillary in soleus muscle of young and middle-aged rats. Acta Physil Scand. 1997; 159: 113-21.

16. Suzuki J, Kobayashi T, Uruma T, Koyama T. Time-course changes in arteriolar and venular portions of capillary in young treadmill-trained rats.Acta Physiol Scandin. 2001; 171:77-86.

17. Deschenes MR, Ogilvie RW. Exercise stimulates neovascularization in occluded muscle without affecting bFGF content. Med Sci Sports Exerc. 1999; 31: 1599-604.

18. Richardson RS, Wagner H, Mudaliar SRD, Saucedo E, Henry R, Wagner PD. Exercise adaptation attenuates VEGF gene expression in human skeketal muscle. Amer J Physiol Heart Circ Physiol. 2000; 279: H772-8.

19. Brown MD, Jeal S, Bryant J, Gamble J. Modifications of microvascular filtration capacity in human limbs by training and electrical stimulation. Acta Physiol Scand. 2001; 173:359-68.

20. Lenasi H, Strucl M. Effect of regular physical training on cutaneus microvascular reactivity. Med Sci Spor Exerc. 2003; 606-12.

21. Simoneau J-A. Adaptation of human skeletal muscle to exercise training. Int J Obesity. 1995; 19(suppl 4): S9-13.

22. Hudlická O. Capillary growth: role of mechanical factors. News Physiol Sci. 1988; 3: 117-20.

23. Hoppeler H, Vogt M. Muscle tissue adaptations to hypoxia. J Exp Biol. 2001; 204: 3133-9.

\section{Correspondence:}

Celina Cordeiro de Carvalho

Rua Rio Tejipió, 183/201

50721-640 Recife-PE Brazil

celina@fir.br
Conflict of interest: none

Financial source: none

Received: July 10, 2006

Review: August 18, 2006

Accepted: September 23, 2006

\section{How to cite this article:}

Carvalho CC, Maux DASX, Tashiro T, Moraes SRA. The effect of endurance training on the neovascularization of skeletal musculature. Acta Cir Bras. [serial on the Internet] 2006 Nov-Dec;21(6). Available from URL: http://www.scielo.br/acb. 